\title{
A REVIEW OF BIOCERAMICS AND FIBRIN SEALANT
}

\author{
L. Le Guéhennec, P. Layrolle and G. Daculsi* \\ INSERM EM 9903, Research Center on Materials of Biological Interest \\ Faculty of Dental Surgery, Place Alexis Ricordeau, 44042 Nantes Cedex, France.
}

\begin{abstract}
This review focuses on bone substitute composites made by mixing ceramic biomaterials with fibrin sealants. Different biomaterials such as coral, bone-derived materials, bioactive glass ceramics, and synthetic calcium phosphate have been mixed with fibrin sealant, resulting in a combination of the biological properties of the two components. This type of association has not produced identical results in all studies. In the past for some, the addition of fibrin sealant to the biomaterial failed to produce any significant, positive effect on osteointegration, whereas others found a positive impact on bone colonization. Despite the negative biological effects reported previously, bioceramic-fibrin composites have been widely used in various types of bone surgery because they are easy to manipulate. In particular, the intra-operative preparation of these composites makes it possible to add bone growth factors or autologous osteoprogenitor cells prior to bone reconstruction. The bone growth factors and autologous osteoprogenitor cells associated with the bioceramic-fibrin composites should provide surgeons with tissue engineered grafts with enhanced osteointegrative properties. This review discusses both the advantages and disadvantages, as well as the future perspectives, of using bioceramic-fibrin composites in various clinical indications.
\end{abstract}

Key words: Bone substitutes, biphasic calcium phosphate, fibrin sealant

\footnotetext{
*Address for correspondence:

G. Daculsi

INSERM EM 9903, Research Center on Materials of Biological Interest

Faculty of Dental Surgery

Place Alexis Ricordeau, 44042 Nantes Cedex, France

Telephone Number: +33-240-412916

FAX Number: +33-240-083712

E-mail: guy.daculsi@sante.univ-nantes.fr
}

\section{Introduction}

Fibrin sealants are biological adhesives that mimic the final step of the coagulation cascade. The main components of the sealant are fibrinogen, plasmatic proteins and factor XIII on the one hand and thrombin, calcium chloride and an antifibrinolytic agent such as aprotinin on the other. The components are extracted from human plasma, except for aprotinin, which comes from bovine lungs, and calcium chloride, which is inorganic. Mixing fibrinogen and thrombin simulates the last stages of the natural coagulation cascade to form a structured fibrin clot similar to a physiological clot. This clot is naturally degraded by proteolytic enzymes from the fibrinolytic system, such as plasmin (Radosevich et al., 1997; Dunn and Goa, 1999). High concentrations of these enzymes are present in res-ponse to tissue inflammation. As a result of their hemostatic and adhesive properties, fibrin sealants have been extensively used in most surgical specialties for over two decades (Mosher and Schad, 1979; Rousou et al., 1989). This is particularly true in intraoperative surgery, where they are used to reduce blood loss and post-operative bleeding.

Several biomaterials have been developed to fill and reconstruct bone defects: natural coral, bovine porous demineralized bone, human demineralized bone matrix (DBM), bioactive glass ceramics and calcium phosphate ceramics such as hydroxyapatite, $\beta$ tricalcium phosphate or biphasic calcium phosphate (Daculsi et al., 1989). All of these materials are biocompatible and osteoconductive, guiding bone tissue from the edges toward the center of the defect. Some materials of biological origin, such as bovine bone (xenografts), DBM and allogenic bone grafts, have osteoinductive properties in sus, making the reconstruction of large bone defects possible. However, biologically-derived materials present a risk of an immunological response and disease transfer, and the manufacturer must apply specific viral inactivation.

The association of bioceramics and fibrin sealants may develop the clinical applications of bone substitutes. The physical, chemical and biological properties of both bioceramics and fibrin glue may be cumulated for preparing advanced bone substitutes. The ideal bone substitute should be biocompatible, biodegradable at the expense of bone growth and moldable, with sufficient mechanical properties to fill and restore bone defects (Bauer and Muschler, 2000). These biological properties can be tailored for both bioceramics and fibrin glue by changing the composition, porosity and network crosslinking.

This paper reviews the literature concerning biomaterials and fibrin sealants. The characteristics of the 
two components, bioceramics and fibrin glue, are described. Preclinical and clinical studies combining ceramic biomaterial and fibrin glue are then reviewed. These studies have not reached the same results. Some studies have reported non-significant, positive results, while others have described excellent osteogenic or osteoinductive properties.

\section{Biomaterials Used as Bone Substitutes}

At present, bone surgeons have three different possibilities when it comes to replacing bone. Although autogenous bone grafts are still considered the gold standard for bone replacement, and allogenic bone grafts are widely used, several ceramic biomaterials have been developed with more or less clinical success. Their main characteristics rely on their ability to be biocompatible, resorbable and osteoconductive.

Autogenous bone grafts are considered as the gold standard for bone replacement, because of their osteoconductive, osteogenic and osteoinductive properties, as well as the absence of immunological rejection. Autografts contain viable osteogenic cells, bone matrix proteins and support bone growth (Bauer and Muschler, 2000). However, the quantity harvested from the iliac crest or other sites is limited and complications have been observed at the additional surgery site. In addition, autologous bone grafts have shown considerable resorption and limited viability because of the lack of vascularization.

Allogenic bone grafts obtained from tissue banks also have limitations because of the possible transmission of non-conventional agents or viruses and the risk of immunological incompatibility (Farrington et al., 1996; Marthy and Richter, 1998). Allogenic bone grafts have both osteoinductive properties (they release morphogenic bone proteins that act on bone cells) and osteoconductive properties, but lack osteogenic properties because of the absence of viable cells (Stevenson and Horowitz, 1992). The harvesting and conservation of allogenic grafts are additional limiting factors (Tomford et al., 1981; Hofmann et al., 1996; Farrington et al. 1998). In view of the limitations of biologically-derived grafts, synthetic bone substitutes have been developed and used clinically for several years.

Bone substitutes are produced in various compositions and shapes. These biomaterials can be used alone to fill bone cavities, serving as a scaffold for bone regeneration from the peri-implant region. Bone substitutes can also be used to supplement autogenous bone or in combination with bone marrow aspirates. The ideal biomaterial should have a variety of forms and sizes, all with sufficient strength for use in load-bearing sites, and also be biocompatible, biodegradable and substituted by newly-formed bone (Bauer and Muschler, 2000). Of these biomaterials, natural coral granules, bovine porous demineralized bone, bioactive glass ceramic and calcium phosphate ceramics such as hydroxyapatite (HA), $\beta$-tricalcium phosphate $(\beta$ TCP) or biphasic calcium phosphate (BCP), and mixtures of the first two have all been developed (Daculsi et al., 1989).

\section{Coral and derived biomaterials}

Natural coral (Porites) consists of a mineral phase, principally calcium carbonate in the structural form of aragonite with impurities such as $\mathrm{Sr}, \mathrm{Mg}$ and $\mathrm{F}$ ions, and an organic matrix. Commercially available coral $\left(\right.$ Biocoral $^{\mathrm{TM}}$ ) is used as bone graft material and reported to be biocompatible and resorbable (Guillemin et al., 1987; Richard et al., 1998). This biomaterial is also osteoconductive and resorbable, resulting in the complete regeneration of bone tissue within 6 months, as shown by radiographic follow-up analysis (Guillemin et al., 1987; Roux et al., 1988; Ouhayoun et al., 1992; Kania et al., 1998). Coral has also been used clinically with good results in spinal fusion (Cunin et al., 2000), cranial surgery (Roux et al., 1988; Arnaud et al., 1994; Arnaud, 2000) or to fill periodontal defects (Yukna, 1994).

Coral-derived material described as coralline HA is also commercially-available (Pro Osteon ${ }^{\circledR}$, Interpore Cross). It is prepared by hydrothermally converting the original calcium carbonate of the coral Porites in the presence of ammonium phosphate (Roy and Linnehan, 1974). This hydrothermal process maintains the original interconnected macroporosity of the coral. Coralline HA was identified as a core carbonated hydroxyapatite (CHA) on inner $\mathrm{CaCO}_{3}$ struts. As a result of this heterogeneity, coralline HA dissolves and reacts inconsistently in vivo (LeGeros et al., 1988; 1991).

Highly porous calcium phosphate ceramics can also be obtained from porous-apatite of lime-encrusted ocean algae (Frios ${ }^{\circledR}$ Algipore $\left.{ }^{\circledR}\right)$. The manufacturing process retains the pure mineral framework of the algae, leaving an interconnected porous structure and a rough surface. It has been shown that the biomaterial is resorbed slowly and substituted by host bone (Schopper et al., 1999).

\section{Bone-derived biomaterials}

Bovine bone-derived materials have also been used either unsintered $\left(\right.$ BioOss $^{\circledR}$, Oxbone ${ }^{\circledR}$, Lubboc $^{\circledR}$, Laddec $^{\circledR}$ ) or sintered around $1000^{\circ} \mathrm{C}\left(\right.$ BonAP, Endobon $^{\circledR}$, Osteograf $\left.{ }^{\circledR}\right)$.

The unsintered materials are usually processed in organic solvents or $\mathrm{CO}_{2}$ super critical fluids to remove the proteins. The remaining bone mineral is principally a carbonated hydroxyapatite (CHA) with a small amount of magnesium, sodium and other trace elements. Its chemical composition and cristallinity is naturally similar to that of bone, with a large specific surface area and macroporosity (Thaller et al., 1993; Merkx et al., 1999). This material has osteoconductive properties and bone formation occurs on its surface while implanted in bony defects. Antigenic or immunogenic inflammatory responses have not been reported with deproteinized bovine bone but its resorption rate is currently the subject of controversy. In some studies, no signs of resorption have been demonstrated (Valentini et al., 1998; Schlegel and Donath, 1998) or only slight resorption (Piatelli et al., 1999). For others, extensive resorption has been observed in animal experiments (Merkx et al., 1999).

Bovine cancellous bone pieces have also been heated around $1000{ }^{\circ} \mathrm{C}$ to burn out the organic components and leave a sintered body. Depending on the sintering 


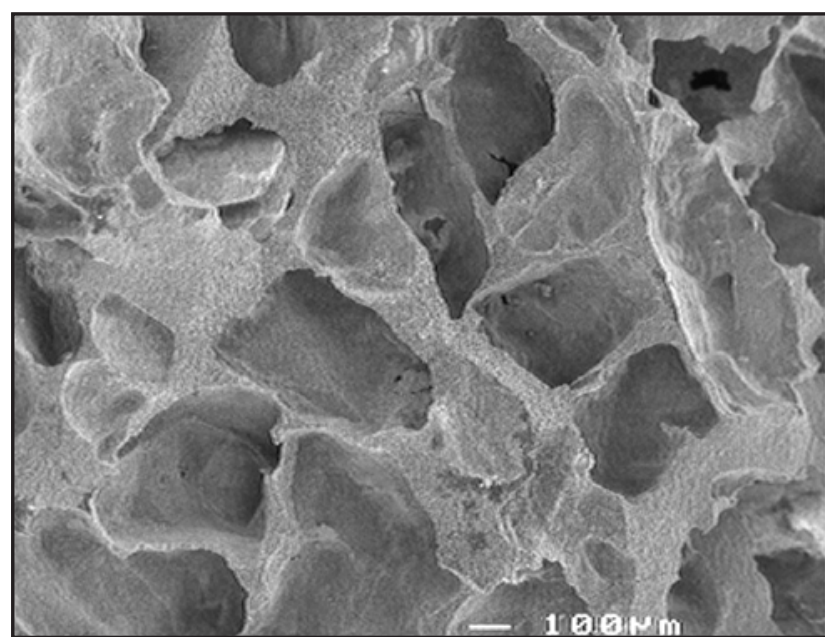

Figure 1. Scanning electron micrograph of $\mathrm{MBCP}^{\circledR}$, Micro Macroporous Biphasic Calcium Phosphate with a $60: 40 \mathrm{HA} / \beta$-TCP ratio and $50 \%$ of macropores ranging from 300 to $600 \mu \mathrm{m}$ in size.

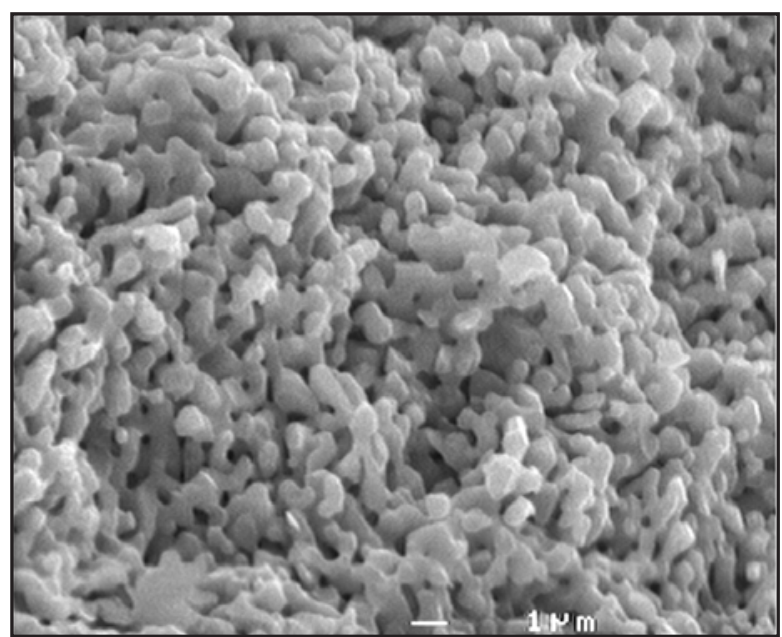

Figure 2. Scanning electron micrograph at greater magnification of $\mathrm{MBCP}^{\circledR}$ showing the micropores and size of the crystals. Microporosity accounts for $30 \%$. conditions, temperature and time, the porosity (micro/ macroporosity) of the original bone is essentially preserved but the phase composition is dratistically changed as the carbonate apatite (CHA) decomposed into HA and B-TCP at high temperatures (LeGeros et al., 1988; 1991; 1992). These materials differ in composition (HA/ B-TCP ratio) depending on the stoichiometry of the initial bovine bone.

\section{Bioactive glass ceramics}

Bioactive glass ceramics (Bioglass ${ }^{\circledR}$ ) are another type of bone substitute (Hench 1971). This glass is biocompatible, osteoconductive and bonds to bone without an intervening fibrous connective tissue interface (Meffert et al., 1985; Schepers et al., 1991). This material has been widely used for filling bone defects (Vogel et al., 2001). When granules of bioactive glass are inserted into bone defects, ions are released in body fluids and precipitate into a bone-like apatite on the surface, promoting the adhesion and proliferation of osteogenic cells (Ohtsuki et al., 1991, Neo et al., 1993). After long-term implantation, this biological apatite layer is partially replaced by bone (Neo et al., 1994). Bioactive glass with a macroporous structure has the properties of large surface areas, which are favorable for bone integration. The porosity provides a scaffold on which newly-formed bone can be deposited after vascular ingrowth and osteoblast differentiation. The porosity of bioglass is also beneficial for resorption and bioactivity (De Aza et al., 2003).

\section{Synthetic calcium phosphate bone subsitutes}

Synthetic calcium phosphates are classified as hydroxyapatite (HA), $\mathrm{Ca}_{10}\left(\mathrm{PO}_{4}\right)_{6}(\mathrm{OH})_{2} \quad\left(\right.$ Cerapatite $^{\circledR}$, Synatite $\left.^{\circledR}\right)$; tricalcium phosphate $(ß-\mathrm{TCP}), \mathrm{Ca}_{3}\left(\mathrm{PO}_{4}\right)_{2}$ (Biosorb $^{\circledR}$, Calciresorb $^{\circledR}$, Chronos $^{\circledR}$ ), biphasic calcium phosphate (BCP) for mixtures of HA and B-TCP (Biosel ${ }^{\circledR}$, Ceraform $^{\circledR}$, Eurocer ${ }^{\circledR}$, MBCP $^{\circledR}$, Hatric ${ }^{\circledR}$, Tribone $80^{\circledR}$, Triosite $^{\circledR}$, TricOs ${ }^{\circledR}$ ); and unsintered or calcium-deficient apatite.

Calcium phosphates have different solubility in vitro or a dissolution rate in acidic buffers, which may reflect the comparative dissolution or degradation in vivo (LeGeros, 1991; LeGeros and LeGeros, 1993; LeGeros et al., 1995a, 1995b). The comparative extent of dissolution is: $\mathrm{ACP}>>\alpha-\mathrm{TCP}>>\beta-\mathrm{TCP}>\mathrm{CdA}>>\mathrm{HA}$.

Calcium phosphate $(\mathrm{CaP})$ biomaterials are available in various physical forms (particles or blocks; dense or porous). One of their main characteristics is their porosity. The ideal pore size for a bioceramic is similar to that of spongious bone. Macroporosity (pore size $>50 \mu \mathrm{m}$ ) is intentionally introduced into the material by adding volatile substances or porogens (naphthalene, sugar, hydrogen peroxide, polymer beads, fibers, etc) before sintering at high temperatures (Hubbard, 1974). Macroposity is formed when the volatile materials are released. Figure 1 shows that the $\mathrm{MBCP}^{\circledR}$ ceramic has macropores ran-ging from 300 to $600 \mu \mathrm{m}$. They account for $50 \%$ of the porosity. Figure 2 shows that microporosity is related to a pore size $<10 \mu \mathrm{m}$. Microporosity is the result of the sintering process, where the sintering temperature and time are critical parameters. It has been demonstrated that microporosity allows body fluid circulation whereas macroporosity provides a scaffold for bone-cell colonization (Daculsi et al., 1990; Daculsi, 1998). An average pore size diameter of 565 $\mu \mathrm{m}$ is reported as the ideal macropore size for bone ingrowth compared to a smaller size $(300 \mu \mathrm{m})$ (Gauthier et al., 1999). The main difference between the different commercially avalaible BCP are the microporosities, which are dependent of sintering process. For osteogenic or osteoinductive properties, the microporosity must be preserved or increased by low temperature processes. Only biphasic calcium phosphates prepared at low temperature (less $1100^{\circ}$ ) are both micro and macroporous.

\section{Fibrin Sealant}

Fibrin sealants are non-cytotoxic, fully resorbable, biological matrices that simulate the last stages of a 
natural coagulation cascade, forming a structured fibrin clot similar to a physiological clot. The fibrinogen component contains a highly concentrated solution of human fibrinogen which, when mixed with thrombin, is converted into fibrin monomers. The premature lysis of the clot is prevented by aprotinin, a fibrinolytic inhibitor (Matras, 1985; Alving et al., 1995). The thrombin component contains highly concentrated human thrombin and calcium chloride solution. The calcium ions are required as cofactors for the enzymatic conversion of fibrinogen into fibrin. The clot is obtained when the thrombin reacts on the fibrinogen peptides, leading to an alteration in the conformation of the molecule and thus an unstable and semi-rigid fibrin clot. The thrombin is activated from its inactive form by factor $\mathrm{Xa}$, in the presence of factor $\mathrm{V}$. The conformation of the fibrinogen molecule is altered, leading to the formation of fibrin monomers. The fibrin monomers polymerize, by means of hydrogen bonds and electrostatic reactions, into unstable, soluble fibrin fibers that elongate and increase in diameter. Thrombin also activates factor XIII in the presence of calcium ions. Factor XIIIa converts the bindings in the fibrin fibers into covalent bindings, leading to the formation of a stable and insoluble clot (Radosevich et al., 1997; Dunn and Goa, 1999).

The fibrin sealant has good tolerability and only a few cases of adverse events have been reported (Alving et al., 1995; Dunn and Goa, 1999). Fibrin sealants have been widely used in bone surgery because of their adhesive and hemostatic properties, but the role of fibrin sealants in bone healing or bone tissue response is controversial. Albrektsson et al. (1982), for example, have reported that fibrin sealant has a negative effect on bone healing. By using a bone growth chamber model in rabbits, it was shown that there was less bone formation in implants treated with fibrin sealant at 5 weeks than in the implants alone. In this study, the fibrin sealant did not improve early bone healing as compared to conventional autologous blood or medullary cells. In another study, conducted by Bösch et al. (1977), the fibrin sealant had a positive effect on bone healing. While fibrin sealant was associated with cancellous bone, radiological and scintigraphic analysis showed earlier bone formation than in the control group. Several reports have recently studied the association of fibrin sealant with bone cells for filling bone defects. Perka et al. (2000) demonstrated a positive effect on bone formation with periosteal cells and fibrin sealant implanted in bone defects in rabbits for 28 days. Bone formation was not detected in the control group composed of fibrin sealant. In heterotopic sites in nude mice, the association of fibrin sealant with periosteal cells led to the formation of newly-formed bone after 12 weeks of implantation (Isogai et al., 2000). Nevertheless, the osteoinductive properties of fibrin sealant have not yet been fully demonstrated and have been the subject of controversory. Isogai et al. (2000) did not observe bone formation at the heterotopic sites in the control group, composed of fibrin sealant alone. In a mouse model, Abiraman et al. (2002) demonstrated the osteoinductive properties for the combination of hydroxyapatite and bioactive glass granules

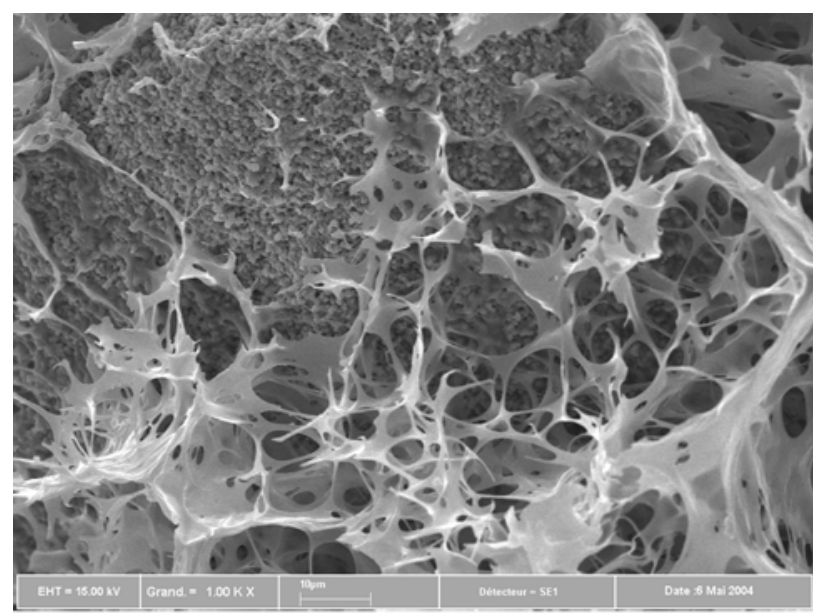

Figure 3. Scanning electron micrograph of the fibrin sealant (Tisseel $\left.{ }^{\circledR}\right)$ and micro/macroporous biphasic calcium phosphate ceramic (TricOs $\left.{ }^{\circledR}\right)$ composite. Note the 3-dimensional fibrin matrix structure in contact with the ceramic surface.

coated with fibrin sealant. These ceramic-fibrin composites implanted intramuscularly in mice produced bone neoformation at 28 days. Similar results were obtained by Yamada et al. (2003) with the association of $\beta$-TCP-fibrin sealant-mesenchymal cells at 8 weeks in heterotopic sites in rats.

\section{Fibrin Sealant-Biomaterial Composites}

Figure 3 shows a composite made of fibrin sealant and micro/macroporous biphasic calcium phosphate ceramic. The 3-dimensional mesh of fibrin sealant interpenetrates the macro- and micro-porous structure of the ceramic. This combination of fibrin sealants and biomaterials may result in their properties being accumulated. The physical properties of this composite are enhanced, with better mechanical resistance than in ceramic alone (Wittkampf, 1989; Marini et al., 1994). Furthermore, initial stability of this bone filler may be achieved through its adhesion to the walls of the bone defect. The biological properties might be also enhanced, thanks to the positive role played by fibrin on vascularization and blood vessel growth in bone defects. Fibrin might also promote the development of blood vessels and the formation of highly vascularized granulation tissue (Nakamura et al., 1998). Fibrin sealants are natural scaffolds for cell attachment and growth (Koolwijk et al., 1996; Takei et al., 1995), and the presence of several growth factors in the fibrin sealant may also have a positive effect during the initial stages of bone colonization (Schmoekel et al., 2004). Despite these elements, the results of the studies performed with fibrin sealant and ceramic biomaterials are nevertheless controversial.

\section{Non-significant positive effects of fibrin sealants on osteogenic properties}

Table 1 summarizes the studies that report an absence of effect or a negative outcome on the combination of fibrin 


\begin{tabular}{|c|c|c|c|c|c|}
\hline BIOMATERIAL & FIBRIN SEALANT & SITE & DURATION & CAUSES & AUTHORS \\
\hline allograft & $\begin{array}{l}\text { Tisseel Immuno } \\
\text { (Canada) }\end{array}$ & $\begin{array}{l}\text { Spine } \\
(\text { dogs })\end{array}$ & 6 months & $\begin{array}{l}\text { Immunologic } \\
\text { reactions between } \\
\text { human, canine and } \\
\text { bovine proteins }\end{array}$ & $\begin{array}{l}\text { Jarzem et al, } \\
1996\end{array}$ \\
\hline coral granules & 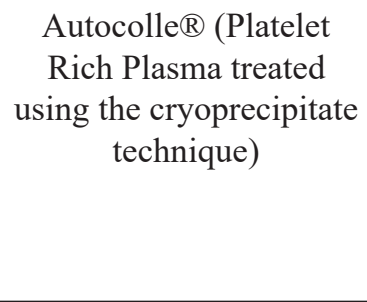 & $\begin{array}{c}\text { Vertebral } \\
\text { bodies } \\
\text { (sheep) }\end{array}$ & $\begin{array}{l}2 \text { and } 4 \\
\text { months }\end{array}$ & $\begin{array}{l}\text { Difficulty for the } \\
\text { osteogenic cells to } \\
\text { infiltrate the } \\
\text { composite } \\
\text { Triggering of chemo- } \\
\text { taxis or inflammatory } \\
\text { cells }\end{array}$ & $\begin{array}{l}\text { Cunin et al, } \\
2000\end{array}$ \\
\hline Bio-Oss $^{\circledR}$ & $\begin{array}{l}\text { Tisseel Immuno AG } \\
\text { Austria }\end{array}$ & $\begin{array}{c}\text { Alveolar } \\
\text { bone (dogs) }\end{array}$ & 10 months & $\begin{array}{l}\text { Impairment of the } \\
\text { early vascularization } \\
\text { of the composite } \\
\text { because of the fibrin } \\
\text { sealant }\end{array}$ & $\begin{array}{c}\text { Carmagnola et } \\
\text { al, } 2000\end{array}$ \\
\hline Bio-Oss ${ }^{\circledR}$ & $\begin{array}{l}\text { Tisseel Immuno AG } \\
\text { Vienna, Austria }\end{array}$ & $\begin{array}{c}\text { Alveolar } \\
\text { bone (dogs) }\end{array}$ & $\begin{array}{l}1 \text { and } 3 \\
\text { months }\end{array}$ & $\begin{array}{l}\text { Impairment of the } \\
\text { early vascularization } \\
\text { of the composite } \\
\text { because of the fibrin } \\
\text { sealant }\end{array}$ & $\begin{array}{c}\text { Carmagnola et } \\
\text { al, } 2002\end{array}$ \\
\hline
\end{tabular}

Table 1: Results from studies showing a negative effect for biomaterial-fibrin sealant composites

sealant and ceramic biomaterials. Most of these reports concerned experimental studies on animals, using commercial fibrin sealant made from products of human origin. Various implantation sites (spine, vertebral bodies, oral cavity) in different animal species (dogs, sheep) were used.

Jarzem et al. (1996) used fibrin sealant with bone allografts for spine fusions in dogs. After 6 months of implantation, the quantity of newly-formed bone was significantly lower in the sites treated with the fibrinallograft composite than in those with the allograft alone. The authors explained that the lower quantity of bone formation was the result of an immunologic reaction between human, canine and bovine proteins present in the fibrin-allograft composite. Cunin et al. (2000) injected coral granules with fibrin sealant into the vertebral bodies of mature sheep. At 2 and 4 post-operative months, bone formation was significantly higher in the cavities filled with coral granules alone than in those filled with coral granules and fibrin sealant. The authors explained the lower quantity of bone growth as being the result of limited infiltration of osteoprogenitor cells into the cavity. The fibrin sealant matrix may have prevented the osteoprogenitor cells from invading the bone defect. Another explanation was the role of the fibrin sealant in triggering chemotaxis or inflammatory cells rather than bone cells. In this process, fibrous tissue healing might have been favored instead of bone regeneration.

In alveolar bone defects in dogs, the combination of fibrin sealant and deproteinized natural bovine cancellous bone mineral (Bio-Oss ${ }^{\circledR}$ ) had a negative impact on bone colonization. Carmagnola et al. (2000) studied tissue reactions around titanium dental implants, which had been inserted into the edentulous ridge of Beagle dogs. The titanium dental implants were surrounded with fibrin sealant-bovine bone graft composites. After 10 months of implantation, connective fibrous tissue was observed between the graft particles as well as on the surface of the implant and host bone tissue. In a previous study, it was shown that bovine bone graft particles (Bio-Oss ${ }^{\circledR}$ ) used without fibrin glue were partly surrounded and substituted by lamellar bone over the same implantation period (Berglundh and Lindhe, 1997).

A similar negative effect of fibrin sealant on bone colonization was corroborated by Carmagnola et al. (2002). Bone defects created on the edentulous ridges of Labrador dogs were filled with bovine bone graft (BioOss $^{\circledR}$ ) and fibrin sealant $\left(\right.$ Tissee ${ }^{\circledR}$ ) composite. At 1 and 3 months after implantation, the defects treated with only the bovine bone graft showed a higher percentage of contact between the graft particles and host bone tissue than the defects filled with the composite. Furthermore, the bone defects filled with the composite had a large proportion of connective tissue that remained unchanged between 1 and 3 months. In both studies (Carmagnola et al., 2000, 2002), the negative effect on bone colonization was blamed on the fibrin sealant. The authors suggest that this component may have impaired the early vascularization of the biomaterial, and thus the bone ingrowth into the defect.

All the studies that show that the combination of fibrin sealant and ceramic biomaterials has negative effects were conducted in animal species using fibrin sealants of human origin. The possible immunologic reactions between components of different origin may jeopardize the colonization of bone cells in the bone defect. Moreover, most of these studies were conducted on a small number of animals and were not always statistically significant. In 


\begin{tabular}{|c|c|c|c|c|c|}
\hline BIOMATERIAL & $\begin{array}{l}\text { FIBRIN } \\
\text { SEALANT }\end{array}$ & SITE & DURATION & RESULTS & AUTHORS \\
\hline $\begin{array}{l}\text { Biphasic calcium } \\
\text { phosphates }\end{array}$ & $\begin{array}{c}\text { Tisseel Immuno AG } \\
\text { Vienna Austria }\end{array}$ & $\begin{array}{l}\text { Mastoid } \\
\text { cavity } \\
\text { obliteration } \\
\text { (human) }\end{array}$ & $\begin{array}{l}2 \text { and } 3 \\
\text { months }\end{array}$ & $\begin{array}{c}\text { Bone } \\
\text { neoformation }\end{array}$ & $\begin{array}{c}\text { Daculsi et al., } \\
\text { 1992; Bagot } \\
\text { d'Arc and } \\
\text { Daculsi, 2003; Le } \\
\text { Guéhennec et al., } \\
\text { 2004; Jegoux et } \\
\text { al., } 2004\end{array}$ \\
\hline $\begin{array}{c}\text { Hydroxyapatite } \\
\text { granules }\end{array}$ & $\begin{array}{l}\text { Tissucol Immuno } \\
\text { AG Austria }\end{array}$ & $\begin{array}{l}\text { Craniofacial } \\
\text { defects }\end{array}$ & 8 years & $\begin{array}{c}\text { Distinct } \\
\text { ossification }\end{array}$ & $\begin{array}{c}\text { Fortunato et al., } \\
1997\end{array}$ \\
\hline $\begin{array}{c}\text { Hydroxyapatite } \\
\text { granules }\end{array}$ & $\begin{array}{l}\text { Tissucol Immuno } \\
\text { AG Austria }\end{array}$ & $\begin{array}{c}\text { Human } \\
\text { maxillofacial } \\
\text { bone defects }\end{array}$ & 2.5 to 8 years & $\begin{array}{l}\text { Prominent } \\
\text { ossification }\end{array}$ & $\begin{array}{c}\text { Bonucci et al., } \\
1997\end{array}$ \\
\hline $\begin{array}{c}\text { Coral granules and } \\
\text { TGF } \beta 1\end{array}$ & $\begin{array}{l}\text { Biocol }{ }^{\circledR} \text { CRTS } \\
\text { Biotransfusion } \\
\text { France }\end{array}$ & $\begin{array}{l}\text { Cranioplasty } \\
\text { (rabbit) }\end{array}$ & 2 months & $\begin{array}{l}\text { Increase in the } \\
\text { rate of minerali- } \\
\text { zation }\end{array}$ & Arnaud, 2000 \\
\hline $\begin{array}{l}\text { Hydroxyapatite } \\
\text { granules }\end{array}$ & $\begin{array}{c}\text { Autologous plasma } \\
\text { cryoprecipitate and } \\
\text { thrombin }\end{array}$ & $\begin{array}{l}\text { Alveolar bone } \\
\text { (human) }\end{array}$ & Several years & $\begin{array}{c}\text { Bone } \\
\text { reconstruction }\end{array}$ & Wittkampf, 1989 \\
\hline $\begin{array}{l}\text { Bovine porous bone } \\
\text { mineral }\end{array}$ & $\begin{array}{c}\text { Autologous } \\
\text { Fibrinogen } \\
\text { Fibronectin system } \\
\text { Preparation }\end{array}$ & $\begin{array}{l}\text { Periodontal } \\
\text { intrabony } \\
\text { defects } \\
\text { (human) }\end{array}$ & 6 months & $\begin{array}{l}\text { Clinical gain in } \\
\text { comparison with } \\
\text { control group }\end{array}$ & $\begin{array}{l}\text { Lekovic et al., } \\
2001\end{array}$ \\
\hline $\begin{array}{c}\text { Bovine porous bone } \\
\text { mineral }\end{array}$ & $\begin{array}{l}\text { Tissucol Immuno } \\
\text { AG Austria }\end{array}$ & $\begin{array}{l}\text { Periodontal } \\
\text { defect } \\
\text { (human) }\end{array}$ & 12 months & $\begin{array}{l}\text { Complete filling } \\
\text { of the defect with } \\
\text { presence of bone- } \\
\text { like hard tissue }\end{array}$ & Re et al., 2002 \\
\hline $\begin{array}{c}\text { Bovine } \\
\text { hydroxyapatite }\end{array}$ & $\begin{array}{r}\text { Tisseel Duo } \\
\text { Quick Immuno } \\
\text { Vienna Austria }\end{array}$ & $\begin{array}{l}\text { Sinus floor } \\
\text { augmentation } \\
\text { (human) }\end{array}$ & 6 months & $\begin{array}{l}\text { Woven bone } \\
\text { bridging bone } \\
\text { trabeculae and } \\
\text { ceramic particles }\end{array}$ & $\begin{array}{l}\text { Hallman et al., } \\
2001\end{array}$ \\
\hline $\begin{array}{c}\text { Bovine } \\
\text { hydroxyapatite }\end{array}$ & $\begin{array}{c}\text { Tisseel Duo Quick } \\
\text { Immuno Vienna } \\
\text { Austria }\end{array}$ & $\begin{array}{l}\text { Sinus floor } \\
\text { augmentation } \\
\text { (human) }\end{array}$ & 3 years & $\begin{array}{l}\text { Newly-formed } \\
\text { bone in contact } \\
\text { with ceramic } \\
\text { particles }\end{array}$ & $\begin{array}{l}\text { Hallman et al., } \\
2001\end{array}$ \\
\hline Coral granules & $\begin{array}{l}\text { Autocolle CRTS } \\
\text { Tours France and } \\
\text { Tissucol Immuno } \\
\text { AG Austria }\end{array}$ & $\begin{array}{l}\text { Bone defects } \\
\text { (rabbits) }\end{array}$ & $\begin{array}{l}1 \text { and } 6 \\
\text { months }\end{array}$ & $\begin{array}{l}\text { Acceleration in } \\
\text { early bone } \\
\text { formation with } \\
\text { fibrin sealant }\end{array}$ & Kania et al., 1998 \\
\hline
\end{tabular}

Table 2: Results from studies showing a positive impact with biomaterial-fibrin sealant composites

order to confirm these negative results, a standard fibrin glue and sufficient number of animals should be used and the data evaluated statistically.

\section{Osteogenic properties of fibrin sealant - ceramic biomaterial composites}

Table 2 summarizes the studies that showed positive effects with combined fibrin sealant and ceramic biomaterials. Unlike the previous, negative, reports, most of these studies concerned clinical results in various osseous sites in humans. A few studies were also performed in small animal models. These different studies were classified in terms of their implantation sites.

In otological surgery, fibrin sealant was used in combination with bioceramic granules. Daculsi et al. (1992) implanted macroporous biphasic calcium phosphate granules mixed with fibrin sealant in mastoid cavity obliteration in both experimental and clinical studies. The clinical and histological results revealed bioactivity and osteoconduction in these composites. Bone neoformation was consistent with normal bone at 2 or 3 months after implantation (Bagot d'Arc and Daculsi, 2003). 
In plastic and reconstructive surgery, fibrin sealantbioceramic composites were used to fill craniomaxillofacial bone defects. Fortunato et al. (1997) and Bonucci et al. (1997) reported the long-term results up to 8 years post-surgery. The clinical and histological results showed integration of the ceramic into the bone tissue. Bioceramic granules were embedded into the calcified bone matrix with no negative reaction such as inflammation or bone resorption. The newly-formed bone underwent a remodeling process similar to that of normal bone. In cranioplasty (Arnaud, 2000), the triple mixture of TGF$\beta 1$, fibrin sealant and natural coral demonstrated efficiency in an experimental model in rabbits, as well as in a limited clinical study. After 3 months, post-operative radiography analysis showed clinical firmness and a new formation of opacity. Cohesion between the fibrin-bone substitute composite and the adjacent bony structures was observed by computed tomography 2 years after implantation.

In oral surgery, fibrin sealant has been used in combination with hydroxyapatite granules to obtain a reconstruction of atrophic ridges (Wittkampf, 1989). A subperiosteal tunnel made it possible to insert this composite at the top of the alveolar ridge in order to reconstruct it. Despite the fact that no histological studies were carried out, this clinical report showed that using a fibrin-bioceramic composite had a positive impact on the reconstruction of atrophic ridges. The surgical group reported excellent clinical results in their well-mastered indication. Fibrin sealant was also associated with spongious bovine bone in the treatment of periodontal intrabony defects in humans by Lekovic et al. (2001). This clinical study, performed on 23 defects, revealed statistically significant improvements in probing depth resolution, gains in clinical attachment and defect filling compared to a control group (spongious bovine bone in combination with enamel matrix derivative). Another positive effect of this association was observed clinically by $\mathrm{Re}$ et al. (2002) on infrabony periodontal defects. In this study, bone-like hard tissue was observed 12 months after surgery. Fibrin sealant was also used in combination with bovine bone-derived hydroxyapatite to perform a maxillary sinus floor augmentation (Hallman et al., 2001a). As early as 6 months after surgery, woven bone was observed in histological biopsies. The woven bone trabecula bridged the host bone and ceramic particles as well as the ceramic particles. Titanium dental implants were inserted into the sinus floor reconstructed previously with the fibrin-biomaterial composite. After 3 years (Hallman et al., 2001b), most of the newly-formed bone was in contact with the ceramic particles. Half the surface of the dental implant was occupied by lamellar bone and a limited amount of immature bone.

The influence of fibrin sealant on the composite has been investigated in a number of experimental studies. Kania et al. (1998) demonstrated the important role played by fibrin sealant in the healing of bone defects. In a study on rabbits, femoral bone defects were filled with coral granules alone or with a mixture of fibrin sealant and coral granules, or were left empty. At 1 month, osteogenesis increased by $46 \%$ with fibrin sealant-coral particles compared to coral alone. At 6 months post-operatively, the cavities filled with the composite showed mature bone similar to that of adult bone in non-operated animals. The same quantity of bone was measured in the group with coral granules alone. This study thus demonstrated that fibrin sealant enhanced bone formation in the early stages following implantation. A study comparing the effect of the main component of fibrin glue demonstrated different bone ingrowth processes on composite of MBCP and fibrin glue (Le Guéhennec et al., 2004). The in vivo evaluation of ingrowth in relation to the composite was made in an experiment on rabbits. The results indicate that in the presence of fibrin sealant, newly-formed bone developed at a small distance from the surface of the calcium phosphate ceramic. Two different bone apposition processes were identified. Without the fibrin component (MBCP group), bone rested directly on the surface of the granules. This observation is commonly described as osteoconduction in calcium phosphate materials. On the contrary, the presence of the fibrinogen component seemed to modify this standard osteoconduction phenomenon: the newly-formed bone essentially grew at a distance from the surface of the granules, on the fibrillar network, and could be considered as an inductive phenomenon for osteogenic cell differentiation from mesenchymal stem cells. Another study conducted by Jegoux et al. (2004) revealed that the influence of different antifibrinolytic agents did not change the osteogenic properties of such a combination of micro-macroporous biphasic calcium phosphate and fibrin sealant.

The positive effects of the combination of fibrin sealant with ceramic biomaterials have essentially been observed in clinical studies. Contrary to experimental animal studies, no immunologic reactions have been reported with fibrin components in human. The fibrin sealant-biomaterial composite has a positive impact on handling and adhesion to the walls of the bone defects. These physical and biological properties are obviously a favorable aspect for surgeons. Unfortunately, there are a limited number of biopsies performed to investigate the osteointegration of the composite in clinical indications. A comparison with experimental animal results is therefore subject to bias and requires further clinical studies.

Fibrin sealant-ceramic biomaterial composites have been developed and tested in several pre-clinical and clinical studies. These composites have been used in a wide range of forms of bone surgery. Fibrin sealants improve the surgical handling of biomaterials and widen their field of application in bone surgery. Furthermore, the future development of this composite may be in combination with bone growth factors. These hybrid composites could enhance bone healing in large defects. Bone morphogenetic proteins (BMPs) play an important role in the growth and differentiation of many different cells during embryogenesis and hemostasis. BMPs act on the differentiation of stem cells into osteoblasts and are important during bone healing and remodeling. Another possible combination involves incorporating bone marrow cells into the fibrin sealant-bioceramic composite. This 
engineering approach to bone tissue should make bone substitutes easier to handle in the operating theatre, as well as provide the scaffold with osteogenic cells from the patient. The combination of cells, fibrin and bioceramics could be an ideal bone graft substitute for reconstructive bone surgery.

\section{Acknowledgments}

The studies were supported by the RNTS 2002 (Réseau National des Technologies pour la Santé), the National Institute for Dental Research of the National Institutes of Health Nos. DE04123 and DE07223 [Dr. R.Z. LeGeros]. We would particularly like to thank Baxter BioSciences Biosurgery, Vienna, Austria and Biomatlante, Vigneux de Bretagne, France for supplying the fibrin sealants and calcium phosphate bioceramics.

\section{References}

Abiraman S, Varma H, Umashankar P, John A (2002) Fibrin sealant as an osteoinductive protein in a mouse model. Biomaterials 23: 3023-3031.

Albrektsson T, Bach A, Edshage S, Jönsson A (1982) Fibrin adhesive system influence on bone healing rate. A microradiographical evaluation using the bone growth chamber. Acta Orthop Scand 53: 757-763.

Alving B, Weinstein M, Finlayson J, Menitove J, Fratantoni J (1995) Fibrin sealant: summary of a conference on characteristics and clinical uses. Transfusion 35: 783-790.

Arnaud E (2000). Advances in cranioplasty with osteoinductive biomaterials: summary of experimental studies and clinical propects. Child's Nerv Syst 16: 659668.

Arnaud E, Morieux C, Wybier M, De Vernejoul MC (1994) Potentiation of transforming growth factor (TGF$\beta 1)$ by natural coral and fibrin in a rabbit cranioplasty model. Calcif Tissue Int 54: 493-498.

Bagot d'Arc M, Daculsi G (2003) Micro macroporous biphasic ceramics and fibrin sealant as a mouldable material for bone reconstruction in chronic otitis media surgery. A 15 years experience. J Mater Sci Mater Medicine 14: 229-233.

Bauer T, Muschler G (2000) Bone grafts materials. An overview of the basic science. Clin Orthop Rel Res 371: 10-27.

Berglundh T, Lindhe J (1997) Healing around implants placed in bone defects treated with Bio-Oss ${ }^{\circledR}$. An experimental study in the dog. Clin Oral Implant Res 8: 117-124.

Bonucci E, Marini E, Valdinucci F, Fortunato G (1997) Osteogenic response to hydroxyapatite-fibrin implants in maxillo-facial bone defects. Eur J Oral Sci 105: 557-561.

Bösch P, Braun F, Eschberger J (1977). Die Beeinflussung der Knochenheilung durch hochkonzentriertes Fibrin. Experimentelle Untersuchung am Kaninchen. (The influence of highly concentrated fibrin on bone repair. An experimental investigation in the rabbit). Arch Orthop Unfall Chir 89:259-273.
Carmagnola D, Berglundh T, Araujo M, Albrektsson T, Lindhe J (2000) Bone healing around implants placed in a jaw defect augmented with Bio-Oss ${ }^{\circledR}$. An experimental study in dogs. J Clin Periodontol 27: 799-805.

Carmagnola D, Berglundh T, Lindhe J (2002) The effect of a fibrin sealant on the integration of Bio-Oss ${ }^{\circledR}$ with bone tissue. An experimental study in labrador dogs. J Clin Periodontol 29: 377-383.

Cunin G, Boissonnet H, Petite H, Blanchat C, Guillemin G (2000) Experimental vertebroplasty using osteoconductive granular materials. Spine 25: 1070-1076.

Daculsi G (1998). Biphasic calcium phosphate concept applied to artificial bone, implant coating and injectable bone substitute. Biomaterials 19: 1473-1478.

Daculsi G, Legeros R, Nery E, Lynch K, Kerebel B (1989) Transformation of biphasic calcium phosphate in vivo: ultrastructural and physico-chemical characterization. J Biomed Mater Res 23: 883 -894.

Daculsi G, Legeros R, Heugheaert M, Barbieux I (1990) Formation of carbonate apatite crystals after implantation of calcium phosphate ceramics. Calcif Tis Int 46: 20-27.

Daculsi G, Bagot d'Arc M, Corlieu P, Gersdorff M (1992) Macroporous biphasic calcium phosphate efficiency in mastoid cavity obliteration: experimental and clinical findings. Ann Otol Rhinol Laryngol 101: 669-674.

De Aza P, Luklinska Z, Santos C, Guitian F, De Aza S (2003) Mechanism of bone-like formation on a bioactive implant in vivo. Biomaterials 24: 1437-1445.

Dunn C, Goa K (1999) Fibrin sealant: a review of its use in surgery and endoscopy. Drugs 58: 863-886.

Farrington M, Mathews I, Foreman J, Cafrey E (1996) Bone graft contamination from a water de-ionizer during processing in a bone bank. J Hosp Infect 32: 61-64.

Farrington M, Mathews I, Foreman J, Richardson K, Cafrey E (1998) Microbiological monitoring of bone grafts: two years experience at a tissue bank. J Hosp Infect 38: $261-271$.

Fortunato G, Marini E, Valdinucci F, Bonucci E (1997) Long-term results of hydroxyapatite-fibrin sealant implantation in plastic and reconstructive craniofacial surgery. J Cranio Maxillofacial Surg 25: 124-135.

Gauthier O, Bouler JM, Weiss P, Bosco J, Daculsi G, Aguado E (1999) Kinetic study of bone ingrowth and ceramic resorption associated with the implantation of calcium-phosphate bone substitutes. J Biomed Mater Res 47: 28-35.

Guillemin G, Patat J, Fournié J, Chetail M (1987) The use of coral as a bone graft substitute. J Biomed Mater Res 21: 557-567.

Hallman M, Cederlund A, Lindskog S, Lundgren S, Sennerby L (2001a) A clinical histologic study of bovine hydroxyapatite in combination with autogenous bone and fibrin sealant for maxillary sinus floor augmentation. Results after 6 to 8 months of healing. Clin Oral Impl Res 12: $135-143$.

Hallman M, Lundgren S, Sennerby L (2001b) Histologic analysis of clinical biopsies taken 6 months and 3 years after maxillary sinus floor augmentation with $80 \%$ bovine hydroxyapatite and $20 \%$ autogenous bone mixed with fibrin sealant. Clin Impl Dent Rel Res 3: 87-96.

Hench LL, Splinter RJ, Allen WC, Greelee TK (1971) 
Bonding mechanisms at the interface of ceramic prosthetic materials. J Biomed Mater Res 2: 117-141.

Hofmann C, Von Garrel T, Gotzen L (1996) Bone bank management using a thermal disinfection system (Lobator SD-1). A critical analysis. Unfallchirurg 99: 498-508.

Hubbard W (1974). Physiological Calcium Phosphate as Orthopedic Implant Material. PhD Thesis, Marquette University, Milwaukee, WI.

Isogai M, Landis W, Mori R, Gotoh Y, Gerstenfeld L, Upton J, Vacanti J (2000) Experimental use of fibrin sealant to induce site-directed osteogenesis from cultured periostel cells. Plast Reconstr Surg 105:953-963.

Jarzem P, Harvey E, Shenker R, Hajipavlou A (1996) The effect of fibrin sealant on spinal fusions using allograft in dogs. Spine 21: 1307-1312.

Jegoux F, Goyenvalle E, Bagot d'Arc M, Aguado E, Daculsi G (2004) In vivo biological performance of composites combining micro-macroporous biphasic calcium phosphate granules and fibrin sealant. Arch Orthop Trauma Surg, in press.

Kania R, Meunier A, Hamadouche M, Sedel L, Petite H (1998) Addition of fibrin sealant to ceramic promotes bone repair: long term study in rabbit femoral defect model. J Biomed Mater Res (Appl Biomater) 43: 38-45.

Koolwijk P, van Erck MG, de Vree WJ, Vermeer MA, Weich HA, Hanemaaijer R (1996) Cooperative effect of TNF-alpha, bFGF, and VGEF on the formation of tubular structures of human microvascular endothelial cells in a fibrin matrix. Role of urokinase activity. J Cell Biol 132: 1177-1188.

LeGeros RZ (1991) Calcium Phosphates in Oral Biology and Medicine. Monographs in Oral Sciences Vol. 15. Myers H (ed). Karger, Basel.

LeGeros RZ, LeGeros JP (1993) Dense hydroxyapatite. In: An Introduction to Bioceramics. Hench LL, Wilson J (eds). World Scientific Publishing, London, pp 139-180.

LeGeros RZ, Kijkowska R, Jia WT, LeGeros JP (1988) Fluoride-cation interaction in the formation and stability of apatites. J Fluor Chem 41: 53-64.

LeGeros RZ, Orly I, Gregoire M, Daculsi D (1991) Substrate surface dissolution and interfacial biological mineralization. In: The Bone-Biomaterial Interface. Davies JE (ed). University of Toronto Press, pp. 76-88.

LeGeros RZ, Daculsi G, Orly I, Gregoire M, Heughebaert M, Gineste M, Kijkowska R (1992) Formation of carbonate apatite on calcium phosphate materials: dissolution precipitation processes. In: Bone Bonding. Ducheyne P, Kokubo T, Van Blitterswijk CA (eds). Rheed Healthcare Communications, New York, NY. pp 201-212.

LeGeros RZ, Bautista C, Styner D, LeGeros JP (1995a) Comparative properties of bioactive bone graft materials. In: Bioceramics in Medicine. Vol 8. Wilson J, Hench LL, Greenspan D (eds). Pergamon Press, New York. pp. 8187.

LeGeros RZ, LeGeros JP, Daculsi G, Kijkowska R (1995b) Calcium phosphate biomaterials: preparation, properties, and biodegradation. In: Encyclopedic Handbook of Biomaterials and Bioengineering. Part A: Materials Vol. 2. Wise DL, Trantolo DJ, Altobelli DE, Yaszemski MJ, Gresser JD, Schwartz ER (eds). Marcel
Dekker Inc., New York. pp 1429-1463.

Le Guehennec L, Goyenvalle E., Aguado E., Pilet P., Bagot d'Arc M., Daculsi G. (2004) MBCP ${ }^{\circledR}$ biphasic calcium phosphate granules and Tissucol ${ }^{\mathbb{B}}$ fibrin sealant in rabbit femoral defects: The effect of fibrin on bone ingrowth. J Mater Sci Mater Med, in press.

Lekovic V, Camargo P, Weinlaender M, Vasilic N, Djordjevic M, Kenney E (2001) The use of bovine porous bone mineral in combination with enamel matrix proteins or with autologous fibrinogen/fibronectin system in the treatment of intrabony periodontal defects in humans. J Periodontol 72: 1157-1163.

Marini E, Valdinucci F, Silvestrini G, Moretti S, Carlesimo M, Poggio C, Bonucci E (1994) Morphological investigations on bone formation in hydroxyapatite-fibrin implants in human maxillary and mandibular bone. Cells Mater 4: 231-246.

Marthy S, Richter M (1998) Human immunodeficiency virus activity in rib allografts. J Oral Maxillofac Surg 56: 474-476.

Matras H (1985) Fibrin seal: the state of the art. J Oral Maxillofac Surg 43: 605-611.

Meffert R, Thomas J, Hamilton K, Brownstein C (1985) Hydroxylapatite as an alloplastic graft in the treatment of periodontal osseous defect. J Periodontol 56: 63-73.

Merkx M, Maltha J, Freihofer H, Kuijpers-Jagtman A (1999). Incorporation of particulated bone implants in the facial skeleton. Biomaterials 20: 2029-2035.

Mosher DF, Schad PE (1979) Cross linking of fibronectin to collagen by blood coagulation Factor XIIIa. J Clin Invest 64: 781-787.

Nakamura K, Koshino T, Saito T (1998) Osteogenic response of the rabbit femur to a Hydroxyapatite thermal decomposition product fibrin sealant mixture. Biomaterials 19: 1901-1907.

Neo M, Nakamura T, Ohtsuki C, Kokubo T, Yamamuro $\mathrm{T}$ (1993) Apatite formation on three kinds of bioactive material at an early stage in vivo: a comparative study by transmission electron microscopy. J Biomed Mater Res 27: 999-1006.

Neo M, Nakamura T, Ohtsuki C, Kasai R, Kokubo T, Yamamuro T (1994) Ultrastructural study of the A-W G$\mathrm{C}$-bone interface after long-term implantation in rat and human bone. J Biomed Mater Res 28: 365-372.

Ohtsuki C, Kushitani H, Kokubo T, Kotani S, Yamamuro T (1991) Apatite formation on the surface of Ceravital-type glass-ceramic in the body. J Biomed Mater Res 25: 1363-1370.

Ouhayoun J, Shabana A, Issakian S (1992) Histological evaluation of natural coral skeleton as a grafting material in miniature swine mandible. J Mater Sci Med 2: 222228.

Perka C, Schultz O, Spitzer R, Lindenhayn K, Burmester G, Sittinger M (2000) Segmental bone repair by tissue-engineered periosteal cell transplants with bioresorbable fleece and fibrin scaffolds in rabbits. Biomaterials 20: 1145-1153.

Piatelli M, Favero G, Scarano A, Orsini G, Piatelli A (1999) Bone reactions to anorganic bovine bone (Bio-Oss) used in sinus augmentation procedures: a histologic longterm report of 20 cases in humans. Int J Oral Maxillofac 
Impl 14: 835-840.

Radosevich M, Goubran H, Burnouf T (1997) Fibrin sealant: scientific rationale, production methods, properties and current clinical use. Vox Sang 72: 133-143.

Re S, Corrente G, Abundo R, Cardarapoli D (2002) Orthodontic movement into bone defects augmented with bovine bone mineral and fibrin sealer: a reentry case report. Int J Periodontics Rest Dent 22: 139-145.

Richard M, Aguado E, Daculsi G, Cottrel M (1998) Ultrastructural and electron diffraction of the bone-ceramic interfacial zone in coral and biphasic calcium phosphate implants. Calcif Tissue Int 62: 437-442.

Rousou J, Levitsky S, Gonzalez-Lavin L, Cosgrove D, Magilligan D, Weldon C (1989) Randomized clinical trial of fibrin sealant in patients undergoing resternotony or reoperation after cardiac operations. A multicenter study. J Thorac Cardiovasc Surg 97: 194-203.

Roux F, Brasnu D, Loty B, Georges B, Guillemin G (1988) Madreporic coral: a new bone graft substitute for cranial surgery. J Biomed Mater Res 69: 510-513.

Roy DM, Linnehan SA (1974) Hydroxyapatite formed from coral skeleton carbonate by hydrothermic exchange. Nature 247: 220- 227.

Schepers E, de Clercq M, Ducheyne P, Kempeneers R (1991) Bioactive glass particulate material as a filler for bone lesions. J Oral Rehabil 18: 439-452.

Schlegel A, Donath K (1998) Bio-Oss: a resorbable bone substitute? J Long Term Eff Med Implants 8: 201209.

Schmoekel H, Schense JC, Weber FE, Gratz KW, Gnagi D, Muller R, Hubbell JA (2004) Bone healing in the rat and dog with non-glycosylated BMP-2 demonstrating low solubility in fibrin matrices. J Ortop Res 22: 376-381.

Schopper C, Moser D, Wanschitz F, Watzinger F, Lagogiannis G, Spassova E, Ewers R (1999) Histomorphologic findings on human bone samples six months after bone augmentation of the maxillary sinus with Algipore ${ }^{\circledR}$. J Long Term Eff Med Implants 9: 203-213.

Stevenson S, Horowitz M (1992) The response to bone allografts. Current concepts review. J Bone Joint Surg 74A: 939-942.

Takei A, Tashiro Y, Nakashima Y, Sueishi K (1995) Effects of fibrin on the angiogenesis in vitro of bovine endothelial cells in collagen gel. In Vitro Cell Dev Biol Anim 31: 467-472.

Thaller S, Hoyt J, Borjeson K, Dart A, Tesluk H (1993) Reconstruction of cranial defects with anorganic bone mineral $\left(\right.$ Bio-Oss $\left.^{\circledR}\right)$ in a rabbit model. J Craniofac Surg 4: 79-84.

Tomford W, Starkweather R, Goldman M (1981) A study of the clinical incidence of infection in the use of banked allograft bone. J Bone Joint Surg (Am) 63: 244248.

Valentini P, Abensur D, Densari D, Graziani J, Hammerle C (1998) Histological evaluation of Bio-Oss ${ }^{\circledR}$ in a 2 stage sinus floor elevation and implantation procedure. Clin Oral Impl Res 9: 59-64.

Vogel M, Voigt C, Gross U, Müller-Mai C (2001) In vivo comparison of bioactive glass particles in rabbits.
Biomaterials 22: 357-362.

Wittkampf A (1989) Fibrin sealant as sealant for hydroxyapatite granules. J Cranio Max-Fac Surg 17: 179181.

Yamada Y, Boo J, Ozawa R, Nagasaka T, Okazaki Y, Hata K, Ueada M (2003) Bone regeneration following injection of stem cells and fibrin sealant with a biodegradable scaffold. J Cranio-Maxillofac Surg 31: 27 33.

Yukna R (1994). Clinical evaluation of coralline calcium carbonate as a bone replacement graft material in human periodontal osseous defect. J Periodontol 65: 177185 .

\section{Discussion with Reviewers}

H. Redl: Could it be the ratio between particles and fibrin, the type of or composition of the used fibrin sealant, e.g., of the used thrombin and fibrinogen concentrations or coarse vs. fine clot structure? It could be that highly concentrated fibrin sealant in too large amounts acts rather as a barrier. So maybe having a table with such data would be very useful. What should be the optimal timing of degradation of fibrin and of the particles? Do we need different composition for different application areas?

Authors: We do not have a table summarizing the best ratio between calcium phosphate and fibrin sealant, or the effect of thrombin concentration on the fibrin structure. This is a review of the literature, and we have no literature references to this. However, we have unpublished data showing that the ratio between ceramic particles and fibrin sealant as well as thrombin and fibrinogen concentrations are indeed critical parameters for tissue ingrowth. Although these parameters are not yet optimized, we typically used a weight ratio between ceramic and fibrin sealant of 50/ 50. Increasing the quantity of fibrin sealant would enhance vascularization and blood vessel growth in the bone defect. On the other hand, a low quantity of osteoconductive ceramic would diminish bone ingrowth. Increasing concentrations of thrombin and fibrinogen should form dense clots acting as barriers for body fluids, cells and tissue. Concerning degradation, the fibrin clot as well as ceramic should first serve as the substrate for osteogenic cells to produce woven bone. Then, the fibrin clot should be rapidly metabolized by macrophage cells. Calcium phosphate ceramics should partly dissolve and be slowly degraded by osteoclastic cells while woven bone is remodelled into mechanically solid tissue. The composition of fibrin sealant - ceramic has a major impact on these biological events and should be adapted to the different clinical indications.

A. Pandit: What distinct advantage does fibrin have over other biodegradable systems such as collagen that have been used to deliver BMP's? Is the osteogenic potential of fibrin dependent on the ratio of fibrinogen and thrombin concentration?

Authors: Fibrin sealants consist of a bi-component system of fibrinogen and thrombin derived from human plasma. When mixed together, these components form a structural 
fibrin clot similar to the physiological clot. The thrombin concentration determines both the setting rate and the clot structure. High thrombin concentrations produce fast setting and a mesh network with thin fibrils and small pore sizes. Fibrin sealants present hemostatic, adhesive, angiogenic and wound healing properties due to the presence of chemotactic and mitogenic factors. Collagen products are usually animal-derived and chemically treated in order to prevent immunological rejections. As a result, collagen products do not contain biological cues such as BMPs that could promote tissue healing. High doses of recombinant BMP should be added to collagen for inducing bone formation. The unbound BMP molecule could be released too rapidly from collagen, which would lead to possible complications at other sites.
J. Czernuszka: How do the authors think this particular composite will compare with other composites, such as collagen:hydroxyapatite (HA), polyhydroxybutyrate:HA, polycaprolactone:HA, polylactic acid:HA?

Authors: Synthetic polymers are slowly degraded after implantation releasing cytotoxic products. Adhesion of cells to the polymers is also not optimal. On the other hand, the fibrin clots are naturally resorbed by macrophages and granulocytes. Furthermore, the rate of biodegradation can be controlled by varying the concentration of the fibrinolytic inhibitor aprotinin. This paper is a review on fibrin alone and the purpose was not to compare fibrin with synthetic polymers. 